\title{
Impact of Linseed Cake in the Diet of Russian Heavy Draft Horses on Productive and Physiological Indicators
}

\author{
Svetlana Sukhanova \\ R\&D Institute \\ "Study of problems in AIC" \\ Kurgan State Agricultural Academy named after T.S. \\ Maltsev \\ Kurgan, Russia \\ nauka007@mail.ru
}

\author{
Nina Pozdnyakova \\ Faculty of Biotechnology \\ Kurgan State Agricultural Academy named after T.S. \\ Maltsev \\ Kurgan, Russia \\ nina_ksaa@mail.ru
}

\author{
Alyona Tarasova \\ R\&D Institute \\ "Study of problems in AIC" \\ Kurgan State Agricultural Academy named after T.S. Maltsev \\ Kurgan, Russia
}

\begin{abstract}
The paper studies the impact of linseed cake in the diet of Russian Heavy Draft growers on their productive and physiological indicators. For the experiment, the Russian Heavy Draft growers were divided into three groups. The reference group of animals had basic diet, the 1st test group had the diet with addition of linseed cake of $\mathbf{3 0 0}$ grams per head a day, the 2nd test group had the diet with addition of linseed cake of 500 grams per head a day. The experiment was carried out in Loginovo LLC in Makushino district of Kurgan region.

In general, the introduction of linseed cake into the diet of Russian Heavy Draft horses had a positive effect on morphological and biochemical blood indicators. The test groups demonstrate reliable increase in the level of hemoglobin, total protein and total nitrogen. Also, the levels of calcium and inorganic phosphorus slightly increase. Over the experiment, the largest gross increment was demonstrated by the second test group: $20.82 \%$ more then in the reference group. In the first test group, this indicator exceeded the reference group by $11.49 \%$. The best results of all measurements and indices of body built were demonstrated by the colts of the second test group. The carcass weight of the animals from the second test group exceeded that of the reference group by $11.92 \%$ and by $5.98 \%$ of that in the first test group. The usage of linseed cake has increased the slaughter yield in the first group by $1.59 \%$, in the second group by $3.08 \%$, as compared to the reference group.
\end{abstract}

Keywords-linseed cake, horses, Russian Heavy Draft.

\section{INTRODUCTION}

Russian Heavy Draft is a breed of small heavy draft horses that is used for farming and as working and breeder horses. Currently, it is the most widely distributed heavy draft horse breed in Russia. This breed is bred almost in every region of the
Russian Federation, excluding Central Federal Districts where they cannot compete with large heavy draft breeds (Sovyetskaya and Vladimirskaya). Having small withers height, Russian Heavy Draft horses possess prominent harness form and substantial live weight. Russian Heavy Draft horses have unsophisticated taste, digest well plain food and preserve their condition. Russian Heavy Draft breed also has good carcass trait and high milk yield, which opens prospects to use this breed for food production.

Correct feeding of horses is a critical factor that conditions their health, working capacity and build-up [10, 13, 14].

Linseed cake is highly dietic. In the horse diet it can be used as an alternative to whole linseed. Linseed cake is of high energy value: $1 \mathrm{~kg}$ of the cake contains $13.73 \mathrm{MJ}$ of metabolic energy and $287 \mathrm{~g}$ of digestible protein and abundant cocktail of microelements and vitamins. Linseed cake protein differs in high digestibility and outstanding aminoacid composition. Fats remaining in linseed cake after oil pressing preserve all useful properties of linseed oil. The unique feature of linseed oil is a high content of alpha-linolenic (omega-3) fatty acid and other non-saturated fatty acids. The content of fatty acids in linseed oil 2 times exceeds that in fish oil. Feeding of growers combines well two processes: accelerated growth and increased final body living weight, i.e. the organism accumulates muscle tissue with contemporary fat accretion on internal organs, inside the muscles and between them and on the carcass surface as well $[1,2,6,7,11]$.

In this connection, the work is aimed at establishing the impact of linseed cake included into the diet of Russian Heavy Draft horses on fertility and physiology. 
To achieve the goal, the following problems were stated:

- $\quad$ establish the morphological and biochemical indicators of the blood of Russian Heavy Draft growers.

- $\quad$ study the growth and development of test animals;

- determine the meat yield of Russian Heavy Draft growers.

\section{METHODS}

The investigation was carried out in Loginovo LLC in Makushino district of Kurgan region during winter-stalled period. To carry out the experiment, the Russian Heavy Draft growers in the age of 9 months after weaning were divided into three groups 9 heads in each according to the principle of analogues with due consideration of gender, age, productivity, origin, physiology and live weight. All keeping and management conditions and microclimate were similar for all test growers. The reference group of animals had basic diet, the 1 st test group had the diet with addition of linseed cake of 300 grams per head a day, the 2nd test group had the diet with addition of linseed cake of 500 grams per head a day.

The full value condition of feeding and health condition of the growers was controlled by studying the content of blood and serum with determination of the content of hemoglobin, white cells, red cells, total protein and its fractions, calcium, inorganic phosphorus, alkaline reserve, total and residual nitrogen.

The live weight of the test young horses was controlled on a monthly basis in the age of $9,10,11$ and 12 months by individual weighting. The parameters of the animals (withers height, heart girth, pastern girth) were measured from the left side by positioning a horse on a flat even ground so it stands on all 4 legs. The measurement was made by a hand stick and measuring band. The indices of body build of growers were calculated by the following equations [15].

The heart-girth index is(\%): $\frac{\text { Heart girth }}{\text { Withers height }} \times 100$

Pastern-girth index is (\%): $\frac{\text { Pastern girth }}{\text { Withers height }} \times 100$.

Density index is (units): $\frac{\text { Weight }}{\text { Withers height }}$.

Mass index is (units): $\frac{\text { Weight }}{\text { Heart girth }}$.

The pastern load index is (units): $\frac{\text { Weight }}{\text { Pastern girth }}$.

To evaluate the carcass traits, a control slaughter of 3 heads from each group in the age of 12 months was performed. Preslaughter living weight, carcass weight, carcass yield, slaughter weight and slaughter yield was taken into account.

The obtained digital data were biometrically processed using Microsoft Excel spreadsheet.

\section{INVESTIGATION RESULTS}

Blood plays essential role in the life of an organism. Blood is responsible for a critical function of living matter, metabolism. Blood is an internal medium where the development and vital activities of an organism take place. It reflects general organization of organism, its constitution and physiology connected with vital functions and living conditions. The blood composition is relatively constant, which provides preservation of species, breed and individual peculiarities of animals. However, the blood composition is fairly labile, which allows using it as an important mechanism for adapting to the fluctuations of living conditions. Thus, practical animal husbandry, hematologic analyses are widely used due to comprehensive functions of blood [3, 4].

The morphological and biochemical indicator of growers' blood in the beginning of the experiment are given in Table 1.

TABLE I - MORPHOLOGICAL AND BIOCHEMICAL INDICATORS OF HORSE BLOOD IN THE BEGINNING OF THE EXPERIMENT $(\overline{\mathrm{X}} \pm \mathrm{S} \overline{\mathrm{x}})$

\begin{tabular}{|l|c|c|c|}
\hline \multirow{2}{*}{\multicolumn{1}{|c|}{ Indicator }} & \multicolumn{3}{c|}{ Group } \\
\cline { 2 - 4 } & reference & 1st test & 2nd test \\
\hline Red cells $\left[\mathrm{x} 10^{12} / \mathrm{l}\right]$ & $8.13 \pm 0.18$ & $8.00 \pm 0.26$ & $8.09 \pm 0.07$ \\
\hline Hemoglobin $[\mathrm{g} / \mathrm{l}]$ & $114.33 \pm 2.15$ & $117.61 \pm 2.09$ & $115.82 \pm 1.66$ \\
\hline Globular value & $0.96 \pm 0.01$ & $1.00 \pm 0.02$ & $0.98 \pm 0.02$ \\
\hline Alkaline reserve [mg\%] & $557.14 \pm 8.07$ & $545.30 \pm 18.55$ & $561.29 \pm 7.25$ \\
\hline Total protein [g/l] & $60.57 \pm 3.52$ & $60.50 \pm 1.53$ & $61.17 \pm 3.37$ \\
\hline Total nitrogen [mg\%] & $993.23 \pm 56.22$ & $968.34 \pm 24.44$ & $1001.13 \pm 54.31$ \\
\hline Residual nitrogen [mg\%] & $23.00 \pm 0.47$ & $22.46 \pm 0.65$ & $22.28 \pm 1.57$ \\
\hline Calcium [mmol/1] & $3.10 \pm 0.04$ & $3.06 \pm 0.06$ & $3.08 \pm 0.04$ \\
\hline Inorganic phosphorus [mmol/1] & $1.61 \pm 0.05$ & $1.63 \pm 0.09$ & $1.64 \pm 0.07$ \\
\hline
\end{tabular}

In the beginning of the experiment, for all horses in all the groups the morphological and biochemical blood indicators were within normal values, which is typical for this breed and age. For instance, the average number of red cells was $8.07 \times 1012 / 1$, hemoglobin content was $115.92 \mathrm{~g} / \mathrm{l}$, globular value was 0.98 , alkaline reserve was $554.58 \mathrm{mg} \%$. The difference between maximum and minimum indicators in the groups was non-reliable: $1.63 \%$ in terms of red cells number, $2.87 \%$ and $2.93 \%$ for hemoglobin content and alkaline reserve, respectively; $4.17 \%$ for globular value.

The level of blood protein components: total protein, total and residual nitrogen on average in all groups correspondingly amounted to $60.75 \mathrm{~g} / 1,987.57$ and $22.58 \mathrm{mg} \%$. The difference between maximum and minimum as per these indicators respectively amounted to $1.11 ; 3.39$ and $3.23 \%$.

The calcium level varied from $3.06 \mathrm{mmol} / 1$ in the 2 nd group up to $3.10 \mathrm{mmol} / \mathrm{l}$ in the reference group; in terms of inorganic phosphorus the variation was from $1.61 \mathrm{mmol} / \mathrm{l}$ in the reference group up to $1.64 \mathrm{mmol} / \mathrm{l}$ in the $2 \mathrm{nd}$ test group. The difference between greater and smaller indicators respectively amounted to: for calcium $1.31 \%$, for indicator phosphorus $1.86 \%$.

The morphological and biochemical indicator of growers' blood in the end of the experiment are given in Table 2 . 
TABLE II - MORPHOLOGICAL AND BIOCHEMICAL INDICATORS OF HORSE BLOOD IN THE END OF THE EXPERIMENT ( $\bar{X} \pm S \bar{X})$

\begin{tabular}{|l|c|c|c|}
\hline \multirow{2}{*}{\multicolumn{1}{|c|}{ Indicator }} & \multicolumn{3}{c|}{ Group } \\
\cline { 2 - 4 } & reference & 1 st test & 2nd test \\
\hline Red cells [x10 $\left.{ }^{12} / 1\right]$ & $8.12 \pm 0.29$ & $8.16 \pm 0.12$ & $8.18 \pm 0.02$ \\
\hline Hemoglobin [g/l] & $116.40 \pm 1.91$ & $127.93 \pm 1.90^{*}$ & $129.73 \pm 1.25^{*}$ \\
\hline Globular value & $0.98 \pm 0.03$ & $1.07 \pm 0.01$ & $1.08 \pm 0.01$ \\
\hline Alkaline reserve [mg\%] & $567.74 \pm 6.03$ & $568.00 \pm 1.57$ & $568.79 \pm 1.74$ \\
\hline Total protein [g/l] & $64.50 \pm 0.38$ & $68.52 \pm 2.21$ & $75.77 \pm 1.67 *$ \\
\hline Total nitrogen [mg\%] & $1058.17 \pm 5.70$ & $1096.64 \pm 35.36$ & $236.94 \pm 27.18^{*}$ \\
\hline Residual nitrogen [mg\%] & $26.17 \pm 0.61$ & $24.68 \pm 0.53$ & $24.18 \pm 1.66$ \\
\hline Calcium [mmol/1] phosphorus & $3.04 \pm 0.13$ & $3.12 \pm 0.07$ & $3.18 \pm 0.16$ \\
\hline $\begin{array}{l}\text { Inorganic } \\
\text { [mmol/1] }\end{array}$ & $1.56 \pm 0.01$ & $1.65 \pm 0.03$ & $1.70 \pm 0.04$ \\
\hline
\end{tabular}

E.V.Eydrigevich, V.V.Raevskaya et al. have established positive dependence between blood oxidation properties and growing rate of livestock growers. Intensely growing animals in the majority of cases have higher oxidation blood properties. Conversely, the decreased growth intensity is accompanied by the reduction of red cells number and blood hemoglobin concentration

By the end of the experiment, the number of red cells in horses' blood was increasing: in the reference group by $0.25 \%$, in the 1 st and 2 nd groups by $0.49 \%$ and $0.37 \%$, respectively. As compared with the reference group, in the 1st test group this indicator was higher by $0.49 \%$ and by $0.74 \%$ in the 2 nd group. This means that the number of red cells was almost constant over the period of the study.

The hemoglobin content behavior was different: the increase in the reference group was $0.55 \%$, in test groups it amounted to $6.07 \%$ and $6.76 \%$, and the hemoglobin level in test groups was reliably $(\mathrm{P} \leq 0.05)$ higher by $9.91 \%$ and $11.45 \%$, respectively, as compared to the reference group. The blood globular value showing the amount of hemoglobin contained in red cells and holding one of the main positions in hematological investigations also changed depending on the introduction of linseed cake. By the end of the experiment, it increased in the reference group by $1.03 \%$, in the 1 st test group by $5.94 \%$, in the 2nd test group by $5.88 \%$. Noteworthily, it almost remained constant in the test groups and was on average higher by $9.69 \%$, as compared to the reference group.

By the end of the experiment, the horses in all the groups demonstrated increased total protein and nitrogen content: by $3.04 \%$ and $3.07 \%$ in the reference group, by $4.87 \%$ and $4.85 \%$ in the 1 st test group and by $10.47 \%$ and $10.33 \%$ in the 2nd test group. During this period, the horses of the 2 nd test group consuming 500 grams of linseed cake demonstrated reliably higher total protein and total nitrogen content as compared to the reference group by $17.47(\mathrm{P} \leq 0.05)$ and $16.89 \%(\mathrm{P} \leq 0.05)$, respectively. In the 2nd test group, the difference of these parameters versus the reference group amounted to: $6.23 \%$ for total protein and $3.64 \%$ by total nitrogen.

Thus, the addition of linseed cake to the diet has increased the protein components of blood (total protein and total nitrogen) with simultaneous decrease of protein decay products (residual nitrogen).
The reference group by the middle of the experiment demonstrated decreased content of calcium by $1.61 \%$ and inorganic phosphorus by $1.86 \%$ that continued decreasing until the end of the experiment by $0.33 \%$ and $1.27 \%$. In the test groups, these indicators conversely increased. By the middle of the experiment, the content of calcium and inorganic phosphorus in the horses' blood serum in the 1st test group increased by $1.31 \%$ and $0.61 \%$, respectively; in the 2 nd test group they increased by $1.30 \%$ and $1.22 \%$, correspondingly. By the end of the experiment, the level of calcium in the 1st and 2nd test groups increased by $0.65 \%$ and $1.92 \%$, respectively, and inorganic phosphorus increased by $0.61 \%$ and $2.41 \%$, correspondingly.

The obtained results allow assuming that the inclusion of linseed cake into the growers' diet had positive impact on morphological and biochemical blood indicators.

Over the postnatal period with low development level and hyponutrition, the colts demonstrate poor development of axial skeleton bones that determine the body width, length and depth. The growth retardation causes changes to the proportions of animal that vary and depend on the stage where the retardation took place. Besides, there are changes to different organs and tissues of an animal, its physiological and biochemical functions. This determines the importance of the studies on the growth and development of colts by their periodical weighting and measurement [16]. The control of their alteration allows concluding the efficiency of the nutrients of tested diet.

The results of monthly control over the changes of the live weight of the tested growers are presented in Figure 1.

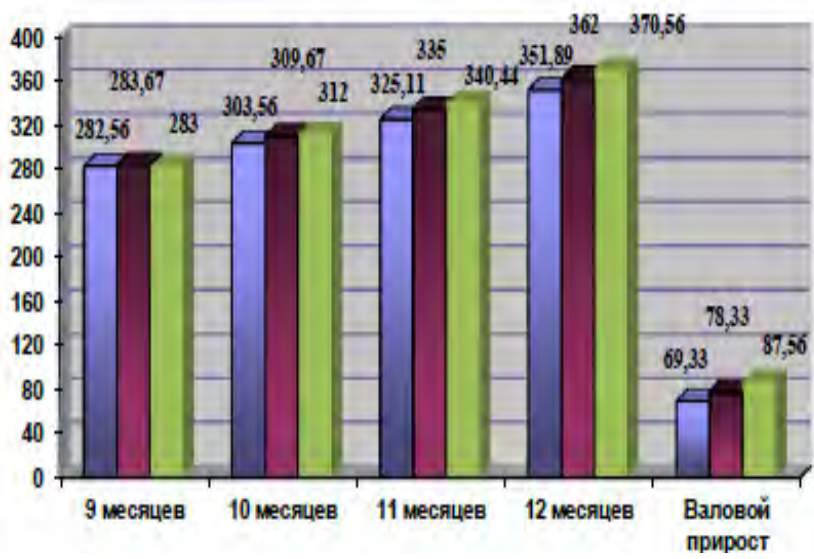

Fig. 1. Live weight dynamics of growers, $\mathrm{kg}$

Live weight of the animals in the beginning of the experiment did not differ much, which witnesses the identity of horse growers included into the groups. By the end of the first month of feeding, the live weight of animals in each group was reliably similar. In the age of 11 months, the live weight of the animals from the reference group was lower than that of the animals from the 1st test group by $9.89 \mathrm{~kg}$ or $2.95 \%$ and by $15.33 \mathrm{~kg}$ and $5.04 \%$ that that of the animals from the $2 \mathrm{nd}$ test group. 
By the end of the test, the difference in the live weight of 12-month animals from the reference group and the 1st test group amounted to $10.11 \mathrm{~kg}(2.79 \%)$; the difference with the 2nd test group was $18.67 \mathrm{~kg}(5.03 \%)(\mathrm{P}<0.95)$.

Over the experiment, the largest gross increment demonstrated the second test group: by $18.23 \mathrm{~kg}(\mathrm{P}<0.001)$ or $20.82 \%$ more than in the reference group. In the first test group, this indicator exceeded the reference group by $9.00 \mathrm{~kg}(\mathrm{P}<0.95)$ or $11.49 \%$.

Thus, the colts consuming linseed cake had higher dynamics of the live weight as compared to the reference animals. The best results in terms of all growth indicators were demonstrated by the animals from the 2 nd test group consuming $500 \mathrm{~g}$ of linseed cake in addition to their basic diet.

The main measurements that characterize the value and proportions of horse body build are:

1. withers height. Measured by the hand stick from the withers highest point vertically to the ground. This measurement characterizes total height of a horse. It is the main measurement to determine the size of a horse.

2. heart girth. Measured by a measurement band over the withers top point and lower edge of the chest down tangentially to the back angle of a shoulder. The heart girth characterizes the massiveness of the carcass, development of the ribcage and relief of the ribs;

3. pastern girth. Measured by a measurement band along the lower edge of upper third of the pastern (in the thinnest part of the pastern). It characterizes the development and total strength of the bones and, to some extent, tendons.

These measurements are used to evaluate the exterior of an adult horse and control the development of growers. Their combination gives fairly complete characterization of the horse body build proportions $[5,8,10]$.

The results of the study on the main measurements of colts in different growth periods are shown in Table 3.

The main measurement indicators and live weight of Russian Heavy Draft growers studied in the experiment correspond to the main measurement indicators of this breed. Furthermore, in all growth periods, the colts from the test groups were superior to the herdmates in the main measurements.

In the end of month 1 of the experiment, the measurements of all animals in the groups were hardly different. In the age of 11 months, the growers from the reference group were inferior to the colts from the 1 st test groups in withers height by 1.17 $\mathrm{cm}(0.96 \%)$; in heart girth by $0.78 \mathrm{~cm}(0.52 \%)$; in pastern girth by $0.1 \mathrm{~cm}(0.05 \%)$. The animals from the 2 nd test group reliably superseded their herdmates from the reference group in withers height by $1.44 \mathrm{~cm}(1.07 \%, \mathrm{P}<0.05)$, in heart girth by $2.78 \mathrm{~cm}$ $(1.82 \%)$, in pastern girth by $0.28 \mathrm{~cm}(1.52 \%, \mathrm{P}<0.05)$.
TABLE III - MEASUREMENTS OF COLTS IN DIFFERENT GROWTH PERIODS, $\mathrm{CM}(\overline{\mathrm{X}} \pm \mathrm{S} \overline{\mathrm{x}})$

\begin{tabular}{|l|c|c|c|}
\hline \multirow{2}{*}{ Measurements } & \multicolumn{3}{|c|}{ Group } \\
\cline { 2 - 4 } & reference & 1st test & 2nd test \\
\hline \multicolumn{4}{|c|}{ Age of 9 months } \\
\hline Withers height & $130.67 \pm 0.53$ & $131.33 \pm 0.47$ & $130.56 \pm 0.34$ \\
\hline Heart girth & $142.57 \pm 1.38$ & $142.89 \pm 1.59$ & $142.11 \pm 0.34$ \\
\hline Pastern girth & $17.97 \pm 0.07$ & $17.91 \pm 0.07$ & $17.97 \pm 0.06$ \\
\hline \multicolumn{4}{|c|}{ Age of 10 months } \\
\hline Withers height & $131.78 \pm 0.60$ & $132.39 \pm 0.33$ & $131.89 \pm 0.42$ \\
\hline Heart girth & $146.67 \pm 1.29$ & $147.44 \pm 1.61$ & $148.00 \pm 0.93$ \\
\hline Pastern girth & $18.90 \pm 0.08$ & $18.04 \pm 0.08$ & $18.20 \pm 0.08$ \\
\hline \multicolumn{4}{|c|}{ Age of 11 months } \\
\hline Withers height & $132.89 \pm 0.59$ & $134.06 \pm 0.32$ & $134.33 \pm 0.29^{*}$ \\
\hline Heart girth & $150.33 \pm 1.31$ & $151.11 \pm 1.91$ & $153.11 \pm 0.89$ \\
\hline Pastern girth & $18.19 \pm 0.09$ & $18.20 \pm 0.11$ & $18.47 \pm 0.08^{*}$ \\
\hline \multicolumn{4}{|c|}{ Age of 12 months } \\
\hline Withers height & $134.78 \pm 0.64$ & $135.06 \pm 0.38$ & $136.22 \pm 0.28^{*}$ \\
\hline Heart girth & $153.44 \pm 1.25$ & $155.11 \pm 1.81$ & $158.22 \pm 0.98^{* *}$ \\
\hline Pastern girth & $18.43 \pm 0.13$ & $18.52 \pm 0.14$ & $18.98 \pm 0.09^{*}$ \\
\hline
\end{tabular}

By the end of the experiment, the colts from the reference group were inferior to the growers from the test group in withers height by $3.0 \mathrm{~cm}(2.2 \%, \mathrm{P}<0.05)$, in heart girth by $4.4 \mathrm{~cm}(3.2 \%$, $\mathrm{P}<0.05)$, in pastern girth by $0.3 \mathrm{~cm}(2.0 \%)$.

To characterize the body build type of horses in horse husbandry, the measurements should be supplemented by indices of body build represented as percentage relation of anatomically connected measurements or measurements of the live weight of a horse (Table 4).

The changes to the indices of horses during individual development depends on the conditions of rearing, feeding, keeping, age, gender, genetic factors, breed and body type [13].

TABLE IV - INDICES OF BODY BUILD OF COLTS $(\overline{\mathrm{X}} \pm \mathrm{S} \overline{\mathrm{x}})$

\begin{tabular}{|l|c|c|c|c|c|}
\hline \multirow{2}{*}{ Group } & $\begin{array}{c}\text { heart girth } \\
{[\%]}\end{array}$ & $\begin{array}{c}\text { pastern } \\
\text { girth [\%] }\end{array}$ & $\begin{array}{c}\text { density } \\
\text { (units) }\end{array}$ & $\begin{array}{c}\text { weight } \\
\text { (units) }\end{array}$ & $\begin{array}{c}\text { pastern } \\
\text { load (units) }\end{array}$ \\
\cline { 2 - 6 } & Age of 9 months \\
\hline \multicolumn{5}{|c|}{ Age of 10 months } \\
\hline reference & $109.09 \pm 0.85$ & $13.75 \pm 0.07$ & $2.16 \pm 0.04$ & $1.98 \pm 0.03$ & $15.73 \pm 0.35$ \\
\hline 1st test & $108.79 \pm 1.01$ & $13.64 \pm 0.05$ & $2.16 \pm 0.03$ & $1.99 \pm 0.03$ & $15.83 \pm 0.23$ \\
\hline 2nd test & $108.86 \pm 0.88$ & $13.75 \pm 0.06$ & $2.17 \pm 0.03$ & $1.99 \pm 0.03$ & $15.77 \pm 0.19$ \\
\hline \multicolumn{7}{|c|}{ Age of 11 months } \\
\hline reference & $111.30 \pm 0.78$ & $13.73 \pm 0.09$ & $2.36 \pm 0.05$ & $2.12 \pm 0.04$ & $17.18 \pm 0.46$ \\
\hline 1st test & $111.36 \pm 1.05$ & $13.63 \pm 0.05$ & $2.37 \pm 0.03$ & $2.13 \pm 0.01$ & $17.40 \pm 0.21$ \\
\hline 2nd test & $112.23 \pm 0.82$ & $13.80 \pm 0.08$ & $2.38 \pm 0.04$ & $2.12 \pm 0.03$ & $17.23 \pm 0.23$ \\
\hline \multicolumn{7}{|c|}{ Age of 12 months } \\
\hline reference & $113.12 \pm 0.72$ & $13.69 \pm 0.10$ & $2.48 \pm 0.04$ & $2.19 \pm 0.03$ & $18.13 \pm 0.40$ \\
\hline 1st test & $112.71 \pm 1.23$ & $13.58 \pm 0.07$ & $2.49 \pm 0.03$ & $2.21 \pm 0.01$ & $18.37 \pm 0.20$ \\
\hline 2nd test & $113.98 \pm 0.73$ & $13.75 \pm 0.08$ & $2.52 \pm 0.04$ & $2.21 \pm 0.03$ & $18.36 \pm 0.23$ \\
\hline \multicolumn{7}{|c|}{} \\
\hline reference & $113.84 \pm 0.64$ & $13.68 \pm 0.11$ & $2.61 \pm 0.04$ & $2.29 \pm 0.03$ & $19.09 \pm 0.30$ \\
\hline 1st test & $114.84 \pm 1.24$ & $13.71 \pm 0.09$ & $2.68 \pm 0.03$ & $2.33 \pm 0.02$ & $19.55 \pm 0.18$ \\
\hline 2nd test & $116.15 \pm 0.74$ & $13.93 \pm 0.06 *$ & $2.72 \pm 0.03$ & $2.34 \pm 0.02$ & $19.52 \pm 0.16$ \\
\hline
\end{tabular}


The index of heart girth increases with the horse's age. This index is used as for evaluating the horse type, as for assessing the conditions of grower rearing and strength of its constitution. By the end of the first month of the experiment, the index of heart girth for all tested animals differed insignificantly. By the 11-month age, this indicator was the largest for growers of the 2nd test group. By the end of the experiment, the index of heart girth of the animals from the reference group was lower by $1.72 \%$ versus the 1 st test group and by $2.31 \%$ versus the 2 nd test group.

The index of pastern girth (boniness) tells about the development of the skeleton and, to some extent, about the constitution strength of a horse (Fig. 2).

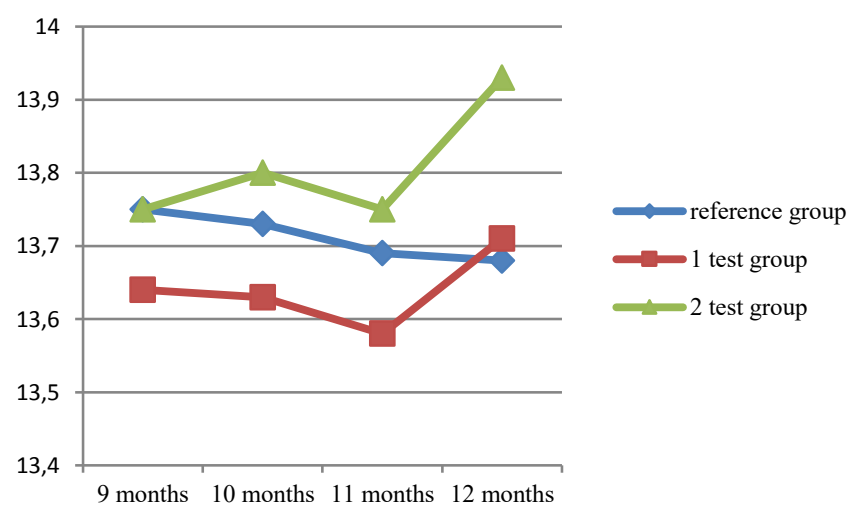

Fig. 2. Dynamics of pastern girth index for horse growers over the experiment, $\%$

In the age of 9 and 10 months, the index of pastern girth of all studied animals had no reliable difference. In the age of 12 months, the index of pastern girth in the 2nd test group of growers was reliably larger by $0.25 \%(\mathrm{P}<0.05)$ than that in the reference group. In the first test group, this indicator exceeded the reference group by only $0.03 \%$. Herewith, over the experiment time, the growers of the reference group demonstrated decreased index of pastern girth by $0.07 \%$ as compared to initial indicator. The horses from the 1 st and 2 nd groups, the index of pastern girth over the experiment time increased respectively by $0.07 \%$ and $0.78 \%$.

The index of density is expressed as a ratio of the animal's weight to the its withers height. This indicator over the whole experiment time increased for all test animals (Fig. 3).

Noteworthily, the growers in the 1st and 2nd groups have larger index of density over the whole experiment time, respectively by 0.07 units $(13 \%)$ and 0.10 units $(18 \%)$, as compared to those from the reference group.

The index of weight behaved similarly to the index of density: the colts from the reference group were inferior to the test animals over all growth periods. Over the whole experiment time, this indicator was higher than in the reference group by $9 \%$ (1st test group) and 11\% (2nd test group).

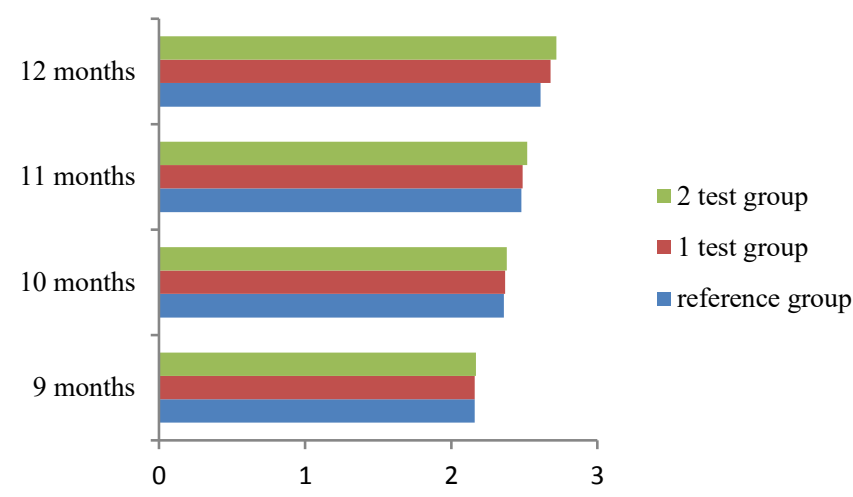

Fig. 3. Dynamics of index of density for horse growers over the experiment time, units

The index of pastern load in all periods of the experiment was the lowest in the reference group. By the end of the experiment, this indicator was largest in the 1st test group, by $2.35 \%$ larger than that in the reference group. The animals from the 2 nd test group were superior to the reference groups in index of pastern load by $2.20 \%$

Thus, the received results tell that the addition of linseed cake to the diet of Russian Heavy Draft horses increased the main measurement and indices of body build.

After the end of the experiment, the reference slaughter of Russian Heavy Draft growers was performed with 24-hour holding. For the slaughter 3 animals were chosen from each group. The investigation results of the meat yield of the test growers are presented in Figure 4.

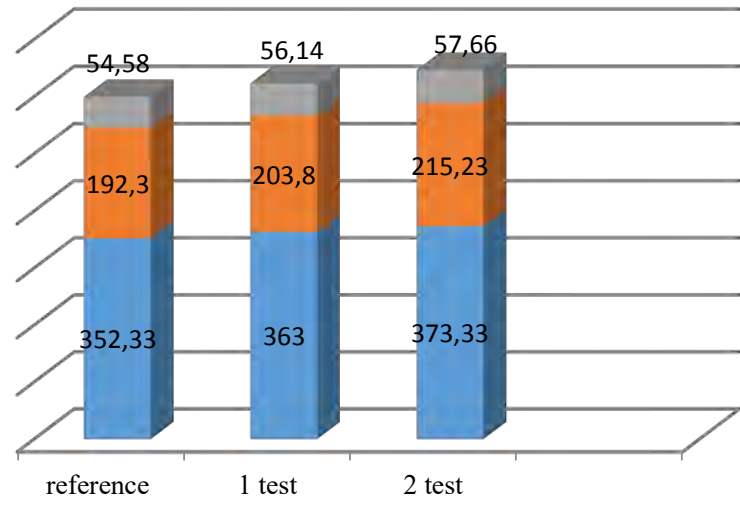

$\square$ Slaughter yield, \% $\square$ Carcass weight, kg $\square$ Pre-slaughter weigth, kg

Fig. 4. Slaughter yield of test growers

Evidently, the slaughter weight and yield of the animals which diet included linseed cake are dominant. The animals in the 1 st test group reliably had heavier carcass by $5.98 \%$ as compared to the reference group $(\mathrm{P}<0.05)$. The growers in the 2 nd test group are superior to the reference group in this indicator by $11.92 \%$ $(\mathrm{P}<0.01)$. The main indicator of the meat yield is slaughter yield. The more the slaughter yield, the more the carcass traits. 
The usage of linseed cake has increased the slaughter yield in the first group up to $56.14 \%$, and up to $57.66 \%$ in the second group, which is $1.56 \%$ and $3.08 \%$ more than in the reference group.

\section{CONCLUSIONS}

After summarizing the study results, one can conclude that the addition of linseed cake to the diet of Russian Heavy Draft growers improves their productive and physiological indicators. The best results in terms of studied indicators were demonstrated by test animals, which diet included linseed cake of $500 \mathrm{~g}$ per head a day.

\section{References}

[1] A.V. Garkovenko, V.V. Radchenko, E.V Ilnitskaya., A.A Bakharev., S.F Sukhanova, "Polymorphism of cattle microsatellite complexes", Journal of Pharmaceutical Sciences and Research, 2018, vol. 10, No. 6, pp. 1545 1551

[2] S.F. Sukhanova, E.I. Alekseeva, N.A. Lushnikov, T.L Leshchuk., S.N Koshelev, G.E. Uskov, N.A. Pozdnyakova, L.G. Dostovalova, "Productive qualities of cattle depending on the breed", The Turkish Online Journal of Design, Art and Communication, 2018, Special Edition March, pp. 419-427.

[3] G.S. Azaubaeva, "Blood picture of animals and birds" (in Russian), Kurgan: Zauralye press, 2004, p. 168

[4] G.S. Azaubaeva, "Productivity from blood analysis" (in Russian), Animal husbandry in Russia, 2004, No. 11., p. 21.

[5] B.Z. Bazaron, "Growth, development and meat productivity of transbaikalian horses and their mixes with Russian Heavy Draft breed", (in Russian), Extended abstract of Cand. Sci. (Agri.), Ulan Ude, 2009, p.
[6] "Biochemical composition of linseed cake and linseed protein" (in Russian), Food and processing industry, Abstract journal, 2006, No. 4., p. 1273 .

[7] G.V. Gurinovich, O. Runda, "Linseed flour and quality of meat chopped half-finished goods" (in Russian), Meat industry, 2013, No. 9, pp. 38-41.

[8] Zh.I. Zdanovskaya, "Comparative estimation of utility and biological features of Russian Heavy Draft and Belorusskaya breeds" (in Russian), Extended abstract of Cand. Sci. (Agri.), Moscow, 2000, p.17.

[9] O.S. Milko, T.N. Golovina, "Problems of breeding work with Russian Heavy Draft breed" (in Russian), Problems and scientific support of horse husbandry in European North of RF, Arkhangelsk-Mezen, 2003, pp. 8385 .

[10] O.S. Milko, I.I. Sorokina, "System for comprehensive evaluation of draft horses of Russian selection using categories of breeding value" (in Russian), Scientific and technological advancement in horse husbandry: Collection of sci. works, VNII of horse husbandry, Ryazan, 2010, vol. 52 ., pp. 107-112.

[11] I.N. Penkova, O.Yu. Mishina, "Non-conventional cakes as means for correcting the quality and ecological safety of livestock rearing products under conditions of technogenesis" (in Russian), Bulletin of Nizhnevolzhsk Agrouniversity Complex, Ecological safety in AIC. Abstract journal, 2015, No. 2, p. 501.

[12] N.A. Pozdnyakova, A.O. Tarasova, "Growth and development of Russian Heavy Draft growers after inclusion of linseed cake into diet" (in Russian), Bulletin of Kurgan SAA, 2018, vol. 26, No. 2, pp. 52-55.

[13] I.I. Sorokina, "Breeding of Russian Heavy Draft breed" (in Russian), State Breeding Book of Russian Heavy Draft horses, Moscow: Kolos, 1982. vol 6., pp. 5-30.

[14] I.I. Sorokina, "Russian Heavy Draft breed" (in Russian), Research on horse husbandry in Russia (1930-2000): Collection of sci. works, VNII of horse husbandry, Divovo, 2001, pp. 158-161.

[15] Fedotov P.A., "Horse husbandry" (in Russian), Moscow: Agropromizdat, 1989, p. 271.

[16] E.V. Eydrigevich, V.V. Raevskaia, "Interior of livestock" (in Russian), Moscow: Kolos, 1966. - 208 p. 